\title{
THREATS TO NORMAL VERNACULAR ARCHITECTURAL HERITAGE OF HISTORICAL CITIES IN CHINA: A CASE STUDY OF HISTORICAL CITIES AND TOWNS IN LIAONING PROVINCE
}

\author{
B. Li ${ }^{1, *}$, Z. Xing ${ }^{1}$, L. Miao ${ }^{1}$, S. Liu ${ }^{1}$ \\ ${ }^{1}$ School of Architecture \& Fine Art, Dalian University of Technology, Dalian, China - (lba_letter, miaoli1001)@126.com, \\ (1291430531, 1770845870)@qq.om
}

Commission II - WG II/8

KEY WORDS: Vernacular Architecture, Liaoning province of China, Normal Heritage

\begin{abstract}
:
Located in the northeastern part of China, the stretch of land named Liaoning is a region historically characterised by the convergence of multiple ethnicities and cultures. It used to be the northeastern boundary of central China with an array of military cities and fortresses intensively built for military defence. Unlike palaces and gentry residences, vernacular residences and urban tissue existing widely in historical towns are excluded in the national protection schedule and have thus experienced different levels of damages. They feature a paradox that the general city form is well preserved whilst architectural forms are changed to a large extent. Most vernacular buildings have endured centennial baptisms, as evidenced by their architectural layouts, structures, roofing, walls, decorations etc. As most historical Chinese cities are not renowned tourist destinations, they are faced with various threats and are on the verge of extinction. The threats include the departure of young residents, decay of historical architecture, insufficient financial and technical support for architectural renovation, improper modifications by residents and demolition of entire historical neighbourhoods. Such threats are widespread in Chinese historical cities which are struggling to survive. Prior to the implementation of professional interventions, the urban forms and vernacular architecture of such historical cities should be studied. Through on-site investigation and query of historical data, especially the historical satellite city maps of U.S. Geological Survey, this study analyses the current life conditions in the context of traditional architecture, reveals problems in the use of historical architecture, identifies potential threats and summarises the underlying reasons. Suggestions benefitting local architectural conservation are then put forward.
\end{abstract}

\section{INTRODUCTION}

Under the rule of the early Ming dynasty in the late 14th century, the building of massive military defence cities reached a rare climax at the northern border of China due to military defence considerations. A series of military defence cities and towns was established in the Liaodong prefecture (presently located within Liaoning Province, south of the Great Wall) at the farthest east end (Wang Guixiang, 2013). These old cities and towns still exist today, and they have become important historical and cultural carriers of this region. In Chinese history, Liaoning was an internal region of the vast Chinese territory and a war-ravaged place with regime changes between northern ethnic minorities and the central Han regime. Liaoning was the cradle of the Qing Dynasty, the last federal dynasty in Chinese history. Manchu people once set their capital (currently Shenyang) here (Geng Qianzheng, 2019).

In the last 40 years, China has experienced rapid urbanisation, yet its historical cities and towns have not received adequate attention and effective protection. Several cities with proper heritage conservation have many vernacular buildings with a history of over a hundred years and well-preserved city forms ( $\mathrm{Li}$ Bing et al., 2018). The heritage of the historical urban tissue becomes living fossils that record the forms and changes of historical cities and towns. Nevertheless, many of these structures are not listed in protection schedules at any level and have rarely been studied. Their historical, cultural and aesthetic value is significantly neglected. They are randomly modified by residents and recklessly demolished by the government and real estate developers.
The current work analyses and explains the threats to existing historical towns with historical neighbourhoods in Liaoning Province from three perspectives, namely, authentic vernacular architecture, remodelled architecture and demolished and newly built architecture. Then, an in-depth analysis of technology, cognition, society and systems is carried out. Conclusions are derived, and strategies and suggestions are presented accordingly. The research methodology of this work combines a comparison of historical satellite images with field investigation. At the beginning of this century, the US Geological Survey published satellite maps of Chinese cities during the Cold War when most historical Chinese cities had not been demolished on a large scale. These maps should be helpful in the search for significant urban changes over the last 40 years.

\section{OVERVIEW OF RESIDENTIAL ARCHITECTURAL HERITAGE IN LIAONING PROVINCE}

Nearly all types of buildings in the historical towns located in Liaoning are courtyards. These buildings include residences, administrative buildings, stores and religious architecture. These yards are often rectangular and built in a south-north direction as long as the terrain allows. Generally, most of these buildings are composed of a principal house facing the south and adjacent houses facing the east and west as auxiliaries. Some courtyards only have two houses that are built parallel or perpendicular to one another. The entrance of a courtyard is often at the centre facing the south. In some exceptional cases, the location and direction of courtyard entrances are rather flexible. One may enter through the principal house in the

\footnotetext{
* Corresponding author
} 
north-south direction or directly pass through the gate on a courtyard wall at the side (Li Bing et al., 2017). Entrances are usually brick wood structures decorated with delicate designs and fitted with dual slope roofs or arc-shaped roofs. A traditional building has three to seven face widths. Under the influences of Manchu and Han, the residential architecture in Liaoning employs an interior wooden beam and a column system, and windows in side gable walls are rarely used. The roofing form is primarily pitched or arc-shaped (Figure 1), with grey tiles, black bricks and ashlar serving as building materials. Such factors constitute a unified and harmonious historical urban and rural landscape.

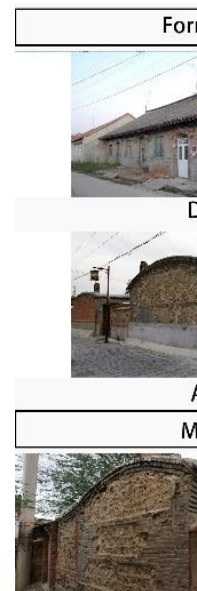

Brick and stone

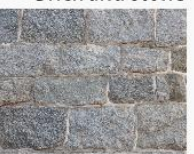

Rubble stone
Forms of Roof

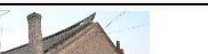

ual slope roof

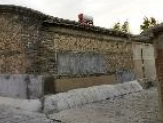

Arc shaped roo Materials

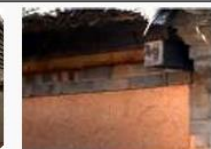

Rammed earth

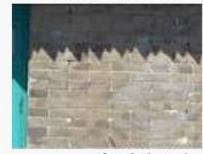

Black bricks

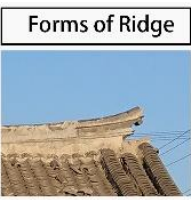

form $A$

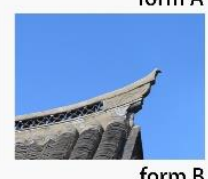

form B

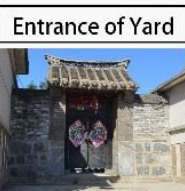

form $A$

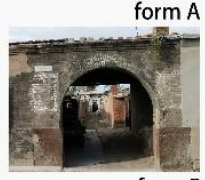

form B

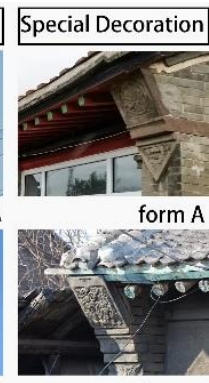

form B
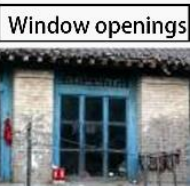

form A

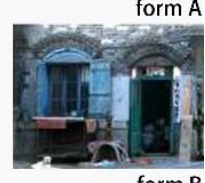

Figure 1. Traditional elements of historical residences in Liaoning Province. Photo by

Li Bing and Xing Zhenpeng, 2016-2019.

\section{DISAPPEARING HERITAGE}

Historical cities and towns in Liaoning were not completely torn down in the 1960s and 1970s following the Great Cultural Revolution. On the basis of the historical satellite photos of the USGS, we can obtain an overview of the previous forms of these historical cities and towns (Figure 2). In the first 30 years of modern China, residential buildings in cities were not encouraged because residential housing was emphasised as a consumer good; by contrast, production spaces such as factories were greatly promoted (Lv Junhua et al., 2003; Huang Quanle, 2015; Xue Fengxuan, 2019). As the population expanded, people were not granted enough living spaces. Correspondingly, traditional urban courtyards became crowded. Since the 1980s, the Chinese economy has grown rapidly, resulting in the development of urban construction. Dilapidated and crowded traditional urban spaces have been massively demolished and replaced mostly with tidy and modern slab-type houses. Normal architectural heritage, except important palaces or ancient official buildings, was not protected at that time, and the same is true today for most historical cities in China. The priority then was to provide housing for the masses, and demolishing old houses and building new ones were recognised as a workable strategy. The same approach has been increasingly promoted in the 21th century because it generates revenues for local governments.
In this century, a large number of Chinese cities, especially metropolises, are no longer disturbed by residential issues and initiated urbanisation. Xingcheng, amongst a few historical cities, has become one of the early tourist cities in Liaoning because of its entirely preserved historical walls and urban tissue. Although many other cities in Liaoning also possess rich historical heritage, they are generally set aside by the public and the government. For various reasons, neglecting heritage, demolishing old houses and building new ones have been playing a dominant role in urban development. Normal architectural heritage can be divided into the following three types in terms of the treatment of vernacular architecture: without any interventions, with spontaneous interventions from residents and with interventions from the government and real estate developers. In the following sections, the pervasive threats to normal vernacular architecture are discussed in detail.
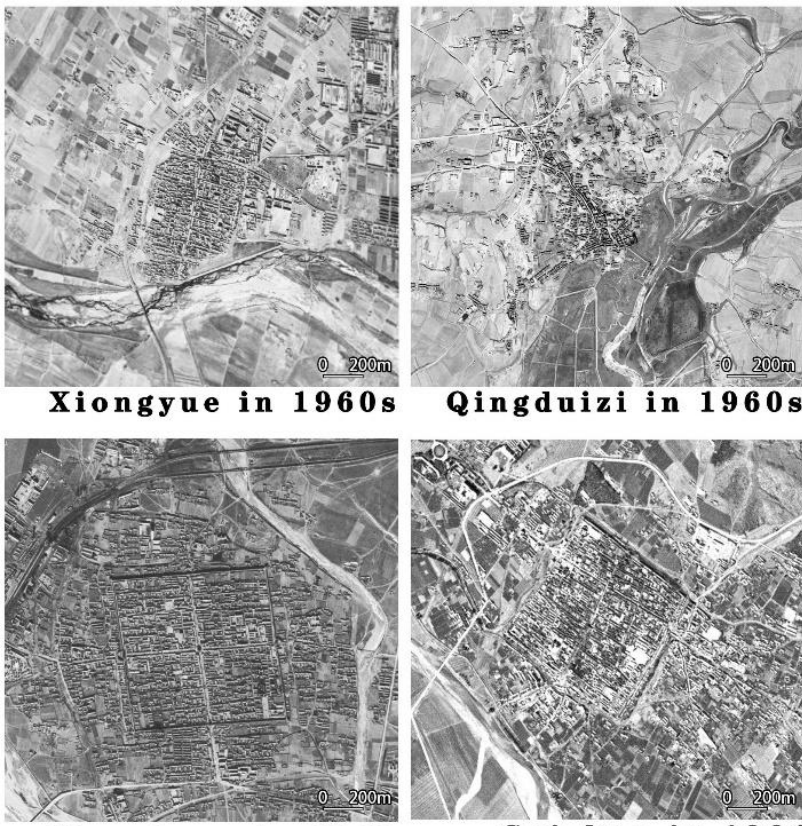

Xingcheng in 1969

Gaizhou in 1964
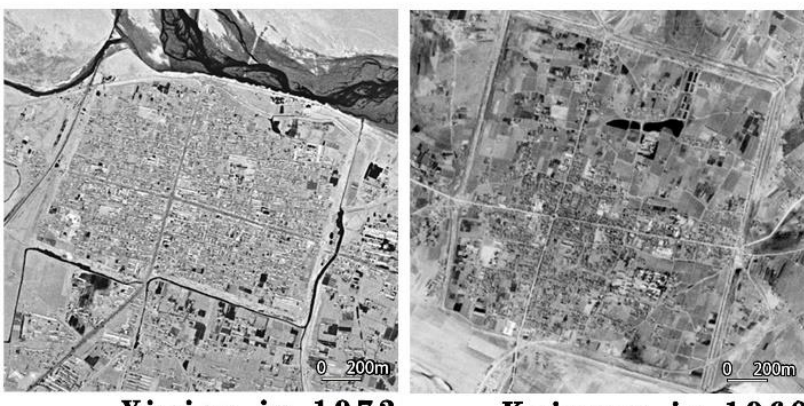

Yixian in 1972

Kaiyuan in 1968

Figure 2. Ancient cities in Liaoning Province in the 1960s1970s. Source: Ancient satellite photos from https://www.usgs.gov/

\subsection{Decay of original vernacular architecture}

Well-preserved normal architectural heritage is uncommon in historical towns. Most residents are unaware of renovation methods for historical architecture whilst only a few craftsmen in Liaoning Province are proficient in such traditional techniques. Renovation with traditional techniques is also expensive. Most of the original normal architectural heritage we see today is not the result of effective renovations as it is left in its original state without improper interventions. 
3.1.1 Incomplete heritage: The decorative components of historical architecture, such as exquisite engravings on gable fronts and delicate cantilevering shapes of roof ridges, are aimed toward refinement. Such decorations symbolise auspiciousness and highlight the exceptional skills of craftsmen. In the 1950s, historical traditions began to be despised as negative and disastrous, and this trend reached its peak during the 'elimination of the four stereotypes' in the Great Cultural Revolution. Many public buildings, including temples and old state bureaus, were knocked down. Despite such fierce movement, nobody was willing to demolish their homes or the residences of others. Accordingly, decorative components became the sacrifice of this movement. People smashed and tore away traditional architectural decorations to show their full resolution to radically break away from the corrupted history. This approach also served as an alternative solution to save their houses from demolition at the expense of losing the essence of the original architectural heritage (Figure 3). In a previous discussion, interviewees shook their heads and sighed to express their anger (Liu Chenglong, 2017). Unlike those under protection schedules, the decorations of normal historical residences that were destroyed were rarely renovated to their original states after the implementation of the reform and opening-up policy.
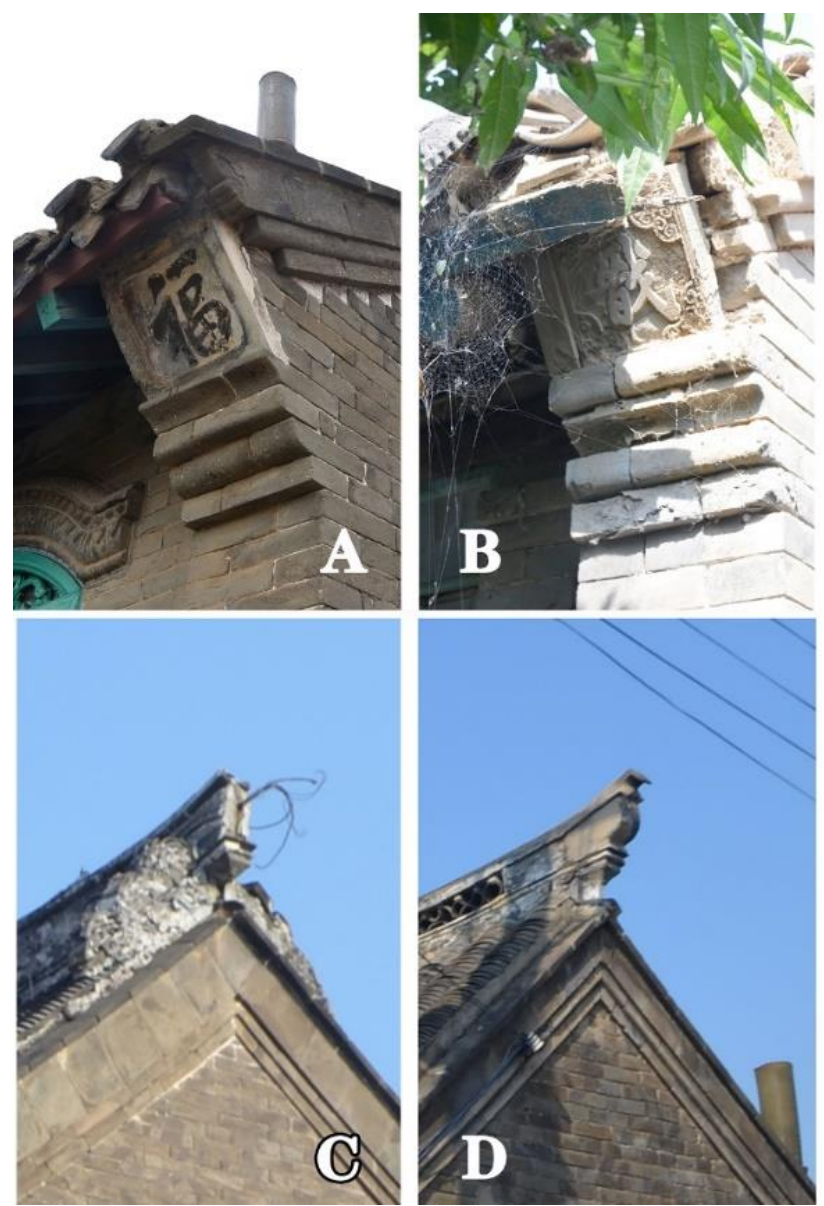

Figure 3. Decorations on vernacular houses in Liaoning Province. B and D show the complete decoration elements. C shows a mutilated element. A presents a simple replacement with drawings. Photo by Li Bing, 2019.

3.1.2 Vernacular architecture left in decay: Unattended historical architecture decays at an astonishing speed. Hidden in small- and medium-sized historical towns in Liaoning are a number of shabby and endangered historical buildings. Such architecture has perfectly preserved historical features which present minimal traces of modern intervention. They are precious textbooks on local vernacular architectural heritage. Some of these buildings were owned by indigenous elderly people, some of whom have either passed away or moved out to live with their children. Historical cities have few tenants due to economic despondency, incomplete infrastructure and lack of modern living facilities, such as independent bathrooms, good heating supply and flat roads. Young generations from these cities often choose to live in their new houses and work in new towns outside this region. They are reluctant to invest money, time or energy to maintain historical buildings for renting or living purposes. Hence, original historical residences are rapidly disappearing (Figure 4).

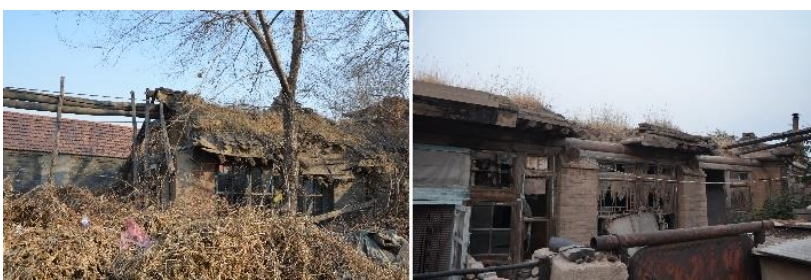

Figure 4. Traditional houses left in decay Left: Ancient town in Kaiyuan; right: ancient town in Xiongyue. Photo by Li Bing, 2016.

3.1.3 Dirty and chaotic public spaces: After the implementation of the reform and opening-up policy, residential houses were widely constructed in different cities across China to address the residential shortage. At that time, an optimal strategy was to flee from old towns and move to live in new buildings in new towns. Previously glorious and attractive traditional streets became messy and embarrassing. Local governments were not motivated enough to pursue the refinement of old city spaces proposed by the central government because the design, implementation and management processes seemed slower and more difficult than the process of tearing down old buildings and replacing them with new ones. During such period, backward towns under economic development could not entirely rely on government investment.

A number of historical towns, such as the historical town of Xiongyue in Yingkou, feature cluttered public street spaces. By the end of 2018, most public streets had not been paved and had thus turned muddy, particularly during the rainy season in summer. Without garbage recycling locations, garbage is discarded casually (Figure 5). Residents living in the old city do not have independent washrooms; they share five latrines in this historical town measuring 8,500 square metres. Hence, the local government hopes to move residents out of the historical city to accelerate its overall renovation and tourism development (Niu Zheng, 2019).
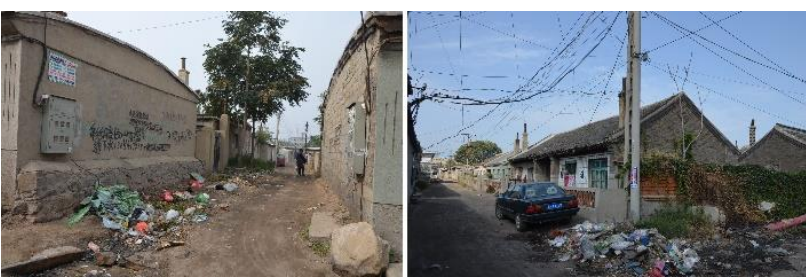

Figure 5. Public hygiene along a street in the old town of Xiongyue. Photo by Li Bing, 2018. 


\subsection{Renovation of normal historical residences}

Historical towns in Liaoning Province have traditionally been residential places. They have retained their historical status until now because of the underdeveloped economic conditions. The government does not have sufficient funds to tear down the old town for new buildings. Local residents are not fully aware of the need to protect architectural heritage that is gradually decaying. They simply renovate their houses into modernised ones on the basis of their needs and current popular trends.

3.2.1 Collapse of courtyards: The land ownership reform after the 1950s transformed traditional family courtyards into large yards inhabited by several households. Before 1980, building residential places fit for population growth was not encouraged in the urban policies of China. Hence, a large number of people lived within limited spaces. They began to build small yards in front of their doors to contain temporary built structures or spaces, including bedrooms, warehouses, kitchens etc. Spacious yards were transformed into narrow passageways which led only to the gates of the yards. The buildings built by the residents could not be compared with traditional architecture in terms of construction quality and aesthetic nature. The divided yards are called 'Za Yuan' (messy courtyards) (Figure 6).
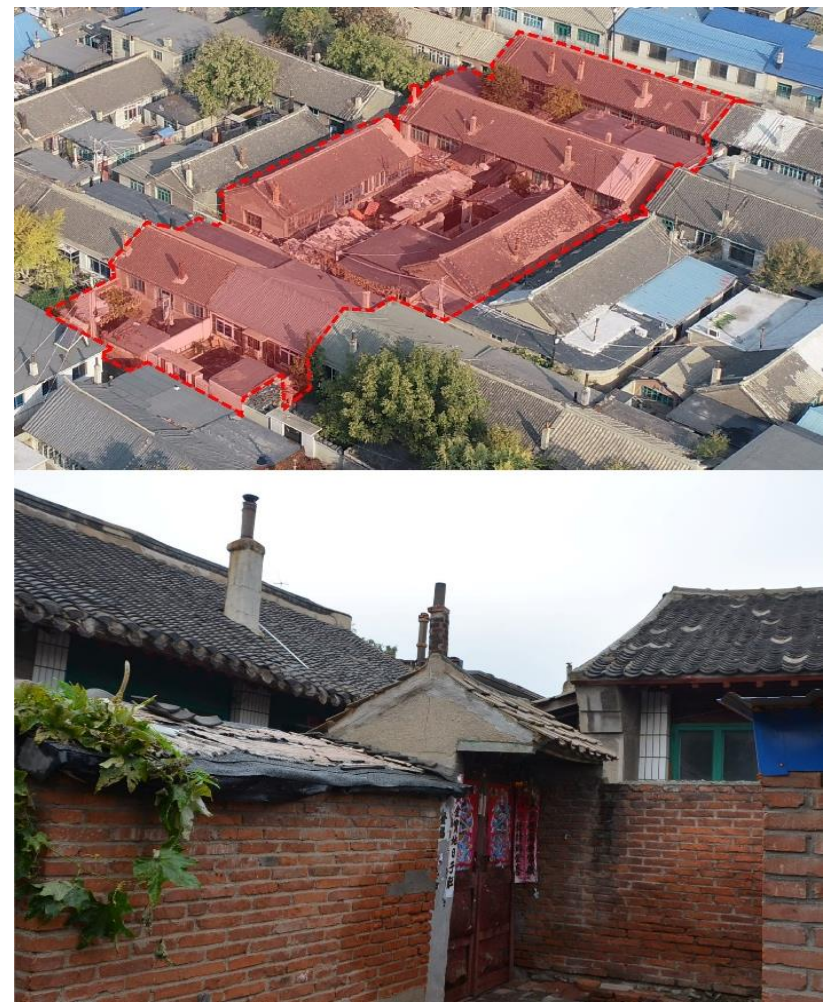

Figure 6. Messy courtyard in the old town of Gaizhou. Photo by Xing Zhenpeng, 2019

3.2.2 Renovation by residents: As for normal residences with residents, owners renovated or rebuilt their houses according to their different needs to improve their living conditions. Guaranteeing a normal life is an old tradition and a necessary process. Historical architecture would lose its vitality without proper self-renovation and repair. However, most cases of renovations by residents in recent decades have accelerated the disappearance of historical architectural heritage. Architects have no opportunity to participate whilst the renovation by residents themselves has deprived historical blocks of creativity and authenticity.
Walls: In historical architecture, the walls are built with dark grey clay bricks and lime bricks measuring less than $2 \mathrm{~mm}$ thick. Cornices and other special parts are adorned with exquisite decorations. Such traditional walls gradually disappear during renovation by residents. The most common approach is to cover historical walls with popular or relatively inexpensive materials, such as grey mortar, granitic plaster and glazed tiles. Thus, the texture of historical architecture becomes overlaid, resulting in the gradual disappearance of the spatial characteristics of historical. Although these practices contradict the style and appearance of traditional architecture, they indeed improve the living conditions of residents. Changes in the aesthetic concepts of residents, in addition to the practical needs of insulation and reinforcement, explain such renovation despite the visual conflicts between such changes and the principle of protecting historical heritage (Figure 7).
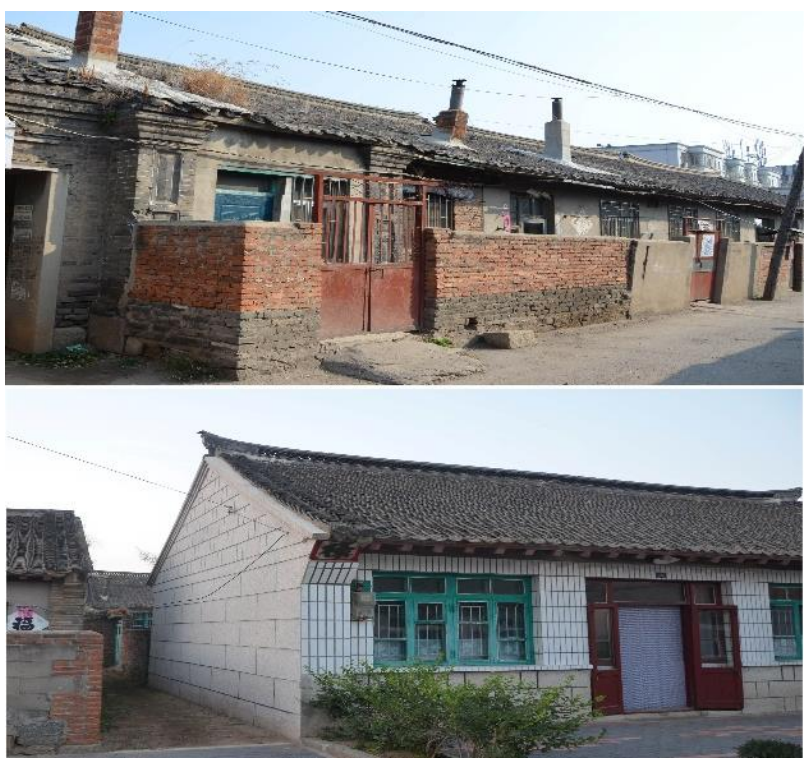

Figure 7. Traditional walls covered by modern materials Source: Li Bing, 2018.

Roofing: Similar to that in traditional architecture in China, the roofing of residences in Liaoning is made of grey pottery tiles. Dripping eave tiles are engraved with various traditional auspicious patterns. Grey pottery tiles are also used to decorate roof ridges. In architectural renovations in the last decade, residents in the historical towns of Liaoning Province have used red or blue steel plates for roofing, placing them on top of the original grey tiles. Known for its low price and convenience in construction, such newly adopted colourful material is common in temporary shelters at construction sites. Moreover, its low cost and effective waterproofing property makes this temporary material particularly popular in the renovation of historical architecture $(\mathrm{Li}$ Bing et al., 2018). However, the use of this material results in a strong visual contrast to the historical city (Figure 8).
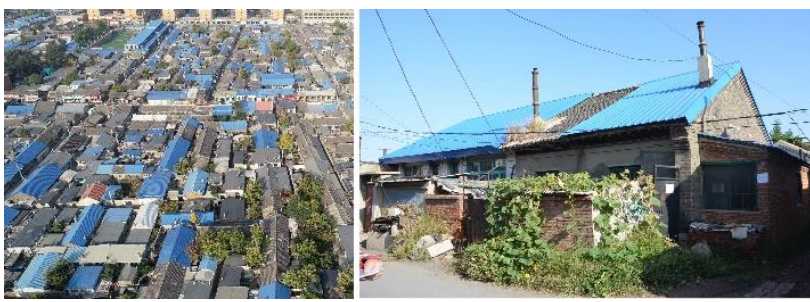

Figure 8. Traditional roofs covered by blue steel plates in the old town of Gaizhou. Source: Xing Zhenpeng and Li Bing, 2019. 
External wall insulation: In some northern historical towns of Liaoning, such as Kaiyuan and Yixian, the climate is relatively cold. Before winter, residents would cover their walls with plastic film on a steel structure, similar to a simple greenhouse, and then remove them in summer. The walls covered with plastic film warm up due to the greenhouse effect. For residents who live in cold regions, such an approach is a practical wind proofing technique to keep warm in winter, although the resulting appearance is strange for traditional architecture. Such renovation addresses practical requirements, but it is not mature enough in the aesthetic sense. Today, residents engage in their own renovations and rarely seek assistance from professional architects (Figure 9). The disappearance of traditional construction materials and the dwindling number of traditional craftsmen have sharply increased the cost of traditional renovation approaches. Residents have no choice but to turn to the most economical way to settle their demand for use. Hence, the reduction of aesthetic quality gradually restricts the traditional landscapes of historical towns.

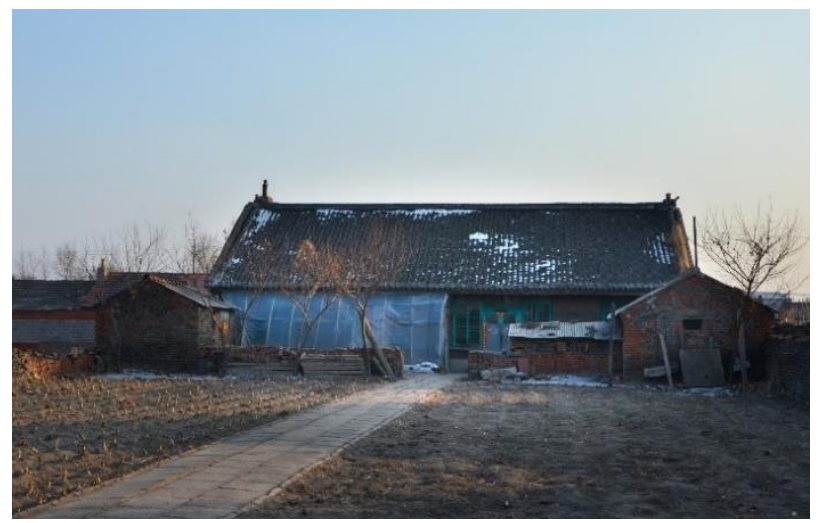

Figure 9. Walls covered with plastic film in the old town of Kaiyuan. Photo by Li Bing, 2017.

\subsection{Demolition and reconstruction of entire historical neighbourhoods}

Whilst residents are voluntarily renovating their houses, local governments take the lead in the old city transformation of large areas. One common approach is to tear down historical neighbourhoods and replace them with new modern residential areas. New collective residences today have evolved from being simple boxes in the 1980s to structures with pitched roofs designed with traditional decorative constructions. Such design seems to be aligned with the characteristics of historical towns.

3.3.1 Vanishing historical blocks: In 2012, some residents in the northwestern district of Xingcheng were encouraged to move outside the city. Soon after that, in 2013, the first 'business and investment attraction project for the purpose of protection and development' was initiated in this historical city. In this socalled 'protection and development' project, residents were actually relocated by the government out of the historical city. The plot where historical blocks were dismantled was sold to real estate developers. Real estate developers then developed tourism projects in accordance with their contracts with the government. They copied the architectural appearance of this historical city and laid out dining areas, accommodations, hot spring facilities and artistic performance venues ${ }^{1}$. They aimed at short-term profits and replaced authentic heritage with counterfeits.
Although such behaviour violates the principle of protecting historical heritage, it has yet to stop. As shown in the satellite map of 2019, the interior and exterior parts adjacent to the city wall of the northwestern district of Xingcheng have been entirely demolished. The same can be observed in a number of historical towns, including Kaiyuan, Yixian and Gaizhou (Figure 10).

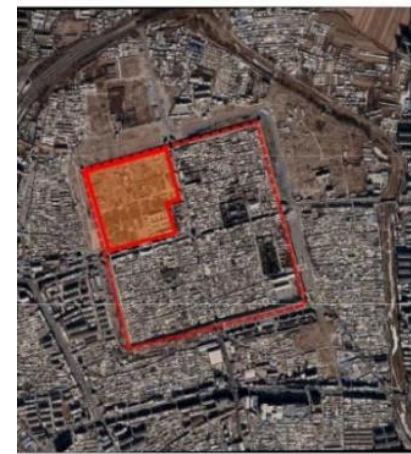

Xingcheng 兴城

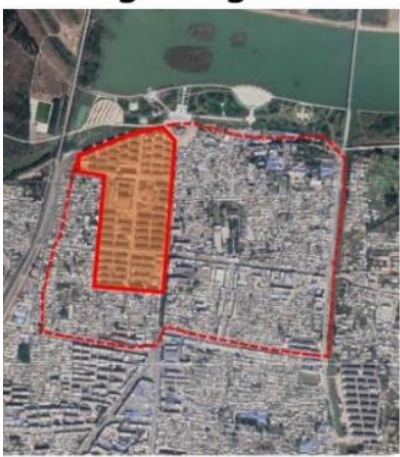

Yixian 义县

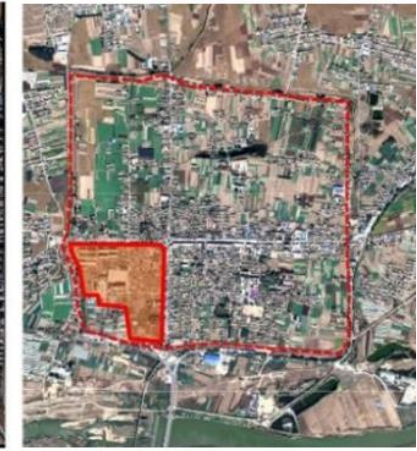

Kaiyuan 开原

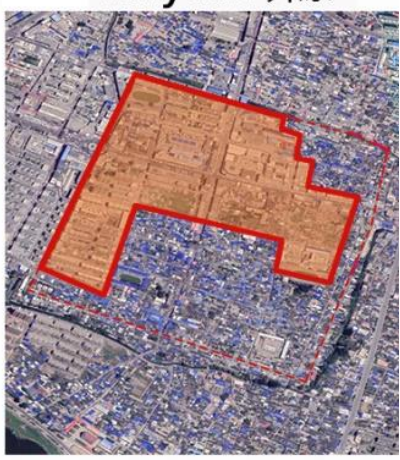

Gaizhou 盖州
Figure 10. Demolition in some old towns of Liaoning Province. Source: Xing Zhenpeng, redrawn based on Google Earth satellite photos of 2016 .

3.3.2 Proliferation of 'fake antiques': When a large part of historical heritage is torn down, people begin to realise its importance. Some authentic and well-preserved historical cities have become popular tourist destinations for this reason. Local governments in Liaoning Province have noticed that historical heritage could boost tourism and economic development. Hence, they have initiated the demolition of historical architecture and the construction of new architecture characterised by 'traditional styles' under slogans such as 'protective development' and 'shantytown transformation'. Such new architecture of distinctive 'historical styles' is also known as 'fake antiques'. Outside the north gate of the old town of Xiongyue, the government built a 'traditional street of the Ming and Qing dynasties', a modern reinforced concrete building with two to three floors and archaised glazed tiles on its pitched roof. A new memorial arch was built at the entrance of the street as a symbol of its business function. Such architecture is significantly incompatible with traditional black bricks, timbre frames and grey tile roofing. This traditional street featuring yellow glazed roofs has been imitated in other historical cities, such as Xingcheng and Kaiyuan in Liaoning and even in many Chinese ancient cities (Figure 11).

1 The first investment project for protection and development in Xingcheng ancient city is landing. 2013-02-27. Journal of Huludao. Source: http://zz.ln.chaoxing.com/article_1745.html 


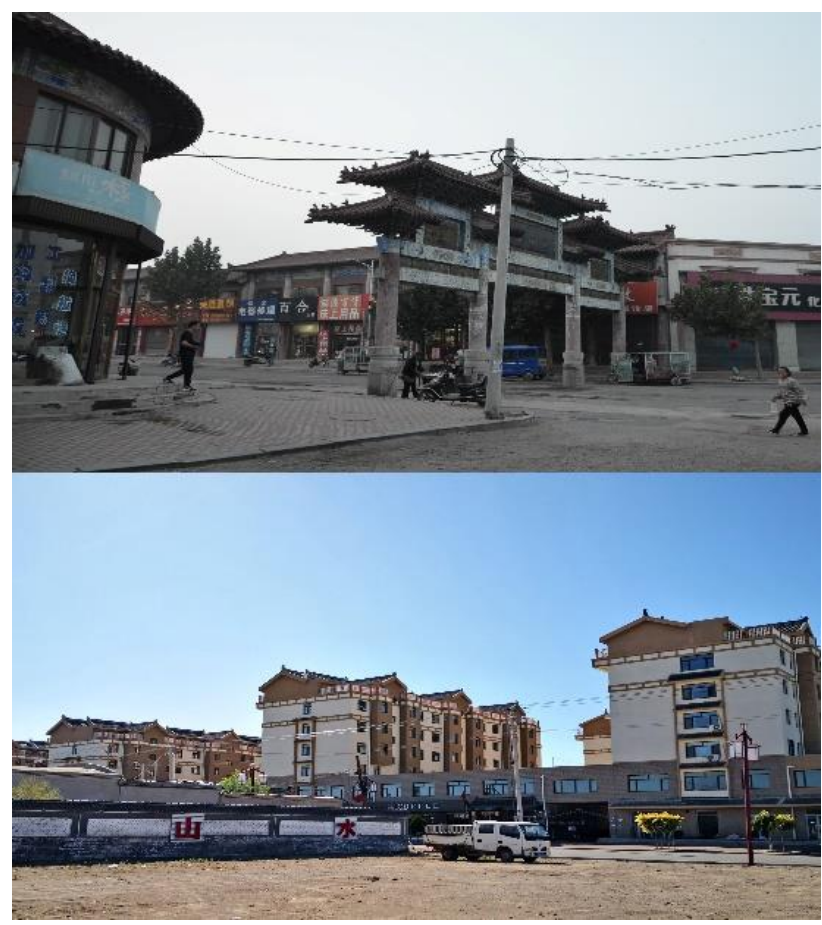

Figure 11. Contemporary buildings with 'traditional style' in Xiongyue and Yixian.

Photo by Li Bing, 2017 and 2019.

\section{ANALYSIS OF THE STATUS QUO OF VERNACULAR ARCHITECTURAL HERITAGE}

\subsection{Decline of traditional craftsmanship and materials}

A serious threat to the historical towns in Liaoning Province is the decline in traditional architectural craftsmanship. The popularisation of reinforced concrete architecture has led to a progressive decline in traditional architecture craftsmanship. Given the sharp drop in market demand, architectural craftsmanship cannot be passed down to new generations. Young craftsmen no longer pursue traditional handicrafts whilst local craftsmen of traditional architecture are too old to continue working. Hiring traditional craftsmen from other places increases costs. Hence, despite their realisation that coloured steel plates do not match the overall look of their towns, the residents of historical towns are left with no solution (Liu Chenglong, 2017).

Widespread modern architecture also leads to the shrinkage of traditional architectural materials. At present, manufacturers producing traditional architectural materials near historical towns are difficult to find. Therefore, locally manufactured red bricks of poor quality are gradually replacing traditional black bricks whilst asbestos shingles, cement tiles or coloured steel plates that are frequently used in modern architecture are employed as roofing materials. Similar traditional materials can be found in the central or southern regions of China, but the price of transport significantly increases the costs of construction. Residents living in historical towns give up the traditional way of renovation as they cannot afford it. As most of these historical towns are not included in any protection schedule, legislation is ineffective in terms of advancing the inheritance of traditional architectural craftsmanship. In addition, no specific regulations, guidelines or economic subsidies are provided by local governments to support the renovation of these residences.

\subsection{Disregard for history and the absence of aesthetic taste}

The understanding of historical urban heritage is an interwoven and repeated process for the Chinese. Before the 1970s, the Great Cultural Revolution 'overturning traditions' dragged down the position of history and traditions in the eyes of the Chinese. The revolution in architectural technology in the past several decades has enabled China to renovate or rebuild architecture using traditional architectural crafts at reasonable prices. Meanwhile, architects and students majoring in architecture in China are not qualified to engage in the building of traditional architecture.

The repeated failures in copying traditional styles onto new architecture have caused people to notice the importance of preserving the authenticity of heritage. People now realise that authentic heritage is a type of non-renewable resource. Unfortunately, protecting the authenticity of heritage lacks a consensus in China, especially amongst government officials, real estate developers and even some researchers at higher institutions. Urban modernisation in the past few decades has caused damage to the reconstruction of vernacular architectural heritage or has eliminated it completely during dismantling. Under the temptation of short-term economic benefits, historical architecture would naturally be sacrificed. Today, this trend continues in China, especially in the northeast region.

Meanwhile, another trend is looming in the Chinese society. Since the beginning of the 1990s, tedious modern architecture and urban spaces have reminded people of the value of historical architecture. Thus, designers of many new buildings have attempted to imitate traditional architecture by stiffly integrating traditional decorative patterns with modern architecture despite its disrespect for history. The above-mentioned 'traditional street of Ming and Qing dynasties' in Xiongyue is a typical example of this trend and is regarded as an unsuccessful attempt at architectural aesthetics.

\subsection{Backward living conditions and lack of economic vitality}

As the basic infrastructure of old urban areas in historical towns is not timely updated, local life is inconvenient. In historical towns in Liaoning Province, backward living conditions are generally embodied in unpaved roads, poor sanitation, lack of independent bathrooms at home, shabby vernacular architecture and extremely underpaid agricultural activities. Furthermore, old urban areas cannot offer sufficient job opportunities. Several old urban areas that are not tourist destinations are mainly used for residential purposes. In the principal streets of old urban areas, private stores serve local residents. Other historical towns have small factories that were built in the peripheral areas before the 1980s. A number of large office areas or business districts are generally located in new urban areas. Accordingly, young locals choose to leave the old towns and embrace the newly built modern urban areas or other developed cities.

The older residents of historical towns are accustomed to the life in these old towns. They are familiar with their neighbours and surroundings, and they do not have high expectations with regard to a new living environment. Consequently, they are willing to give up their savings to young generations and help them live a modernised life. As for themselves, they have no passion or money to renovate their old houses. Therefore, few young people stay in old towns, and old houses are left unattended once their elderly residents leave. Such factors accelerate the decay of these houses. 


\subsection{Collapse of private property rights and the land requisition of the government}

Courtyards, as a basic unit of historical towns in China, are a spatial demonstration of the family-based social structure in an agrarian society. Once the structural units of a society change, spatial units are altered accordingly. The transformation of historical cities in China began in the 1950s, during which the property rights system was reformed. The original family courtyard was assigned to multiple households. In the early days, a courtyard is a public space for public communication. However, as children grew up, got married and had their own children, few independent living spaces were provided or allocated to them by the local government (Lv Junhua et al., 2003). Consequently, the previous spacious yards collapsed and became occupied by different households.

More important, the practical operation of projects emphasises short-term economic returns under the current economic development model and leadership tenure system of China. Renovating authentic heritage is time consuming and lacks immediate profits, whereas urban development achieves the socalled 'all-win' pattern by demolishing historical architecture, selling land to real estate developers at high prices and allowing them to build archaised buildings, which are quite popular nationwide (Li Bing, 2012; Huang Quanle, 2015). Under this short-sighted development pattern, the non-renewable heritage is permanently lost.

\section{CONCLUSION}

Chinese traditional residential houses have undergone thousands of years of inheritance and evolution. As increasing attention is paid to traditional culture in present China, letting vernacular architecture and historical towns vanish is unacceptable. In the region of Liaoning, where damage is severe and vernacular architecture is not as rich as that in other Chinese regions, historical architecture is entitled with precious and scarce values. Even the residential type of 'living heritage' sites being protected by the country is quite vulnerable (SHAO Yong, 2016), and the same is true for the historical towns in Liaoning Province (except Xingcheng and Gaizhou) that are not included in any protection schedule. Meanwhile, the protection of traditional residences in Liaoning is extremely difficult. Perfectly preserved courtyards and traditional architecture are countable in these historical towns. Most of the architecture has been damaged to different extents and has thus received little attention from the local government and the general public.

From the discussion above, we can summarise necessary strategies and suggestions from a technical perspective so as to avoid and reduce the damages to historical architecture. The strategies and suggestions are listed as follows:

1. Local governments should restore and encourage the heritage of traditional architectural craftsmanship and the production of traditional construction materials. They should integrate technological solutions in accordance with the heritage protection philosophy and collaborate with professional designers for the renovation of residential architecture;

2. The city master plan should be supplemented with heritage protection items to ensure the uniformity of the urban development and legally protect vernacular dwellings.
3. In the well-preserved historical districts of old towns, the well-preserved authentic historical buildings should be maintained and renovated, and damaged architectural components should be replaced or repaired in a traditional way. Examples of successful renovations of traditional architecture should be set, and local residents' recognition of the historical and architectural value of their hometowns should be enhanced.

4. At present, the development patterns of China's society are different from those in the handicraft age. Changes in manufacturing and living conditions have triggered the evolution of architectural forms. Hence, renovating vernacular architecture in light of its authenticity is extremely challenging. We should proactively introduce outstanding architects and heritage research institutions and creatively renovate traditional architecture according to residents' demands. Reasonable agreements should be made between both parties, and the renovation should be jointly funded by the government and the residents.

At the cognitive level, the entire society should boost their recognition of the value of historical architecture. Experts should collaborate with governments to promote books, publicity campaigns and TV programmes about local traditional architecture. Through these efforts, they can boost the society's recognition and protection of local historical architecture. Decision makers' cognition is the key to this process. Their attitudes toward heritage largely determine the direction of historical towns in Liaoning Province. For normal vernacular architecture, the buildings and their surrounding environments should be included in the heritage protection list. At the same time, the natural environments and existing historical construction environments should be protected. Damage to heritage disguised as 'protection and utilisation' rather confuses the public in present-day China.

At the social level, we should boost local economic vitality, ameliorate public spaces in historical towns and improve public services. These efforts should be made on the premise of protecting local architectural heritage. Once the local environment is improved, it will attract outside residents searching for work and living spaces and thereby boost the economic development.

The dilemma of the government is choosing to either reap shortterm economic benefits by demolishing old houses and building new ones or pursue long-term interests by protecting authentic heritage and thereby improving the life quality of residents. In essence, the issue is aligned with the design and orientation of the administration system and is not exactly a professional issue for architects, designers or heritage protection scholars. Nevertheless, experts and scholars should continue their efforts to communicate with the government.

\section{ACKNOWLEDGEMENTS}

This research was supported by a grant from the Project of Social Science Planning Fund of Liaoning Province (No. L19BBZS002), P.R. China. 


\section{REFERENCES}

Geng Qianzheng, 2019. Research on the Form of Military Towns of Ming Dynasty in Liaodong Prefecture under the Urban Morphological Perspective. Dalian University of Technology.

Geng Qianzheng, Li Bing, Miao Li,2018. Study on Urban from Characteristics of Wei-

Towns in Ming Dynasty, Liaoning Province: Cases of Gaizhou, Kaiyuan and Xingcheng. Urbanism and Architecture, 2018(36), p. 96-98.

Huang Quanle, 2015. Metropolis of Rurality: A Spatial History of Shipai in Guangzhou from the Perspectives of Typomorphology (1978-2008). Beijing: China architecture \& building Press.

Li Bing, 2012. Patrimoine et mutation urbaine dans le cadre du développement touristique. Paris:Université de Paris 1(Panthéon-Sorbonne).

Li Bing, Geng Qianzheng, Du Nanhua, Miao Li, 2018. A Study on the Urban Form Evolution of Ancient Towns in Coastal Hilly Areas of Northern China: A Case Study on the Qingduizi Ancient Town in Zhuanghe. Urbanism and Architecture, 2018(24), p. 122-125.

Li Bing, LI Yanqiao, Miao Li, Liu Chenglong, 2017. Exploring the Status and Strategy of Traditional residences Transformations of Ancient Town in Liaodong Peninsula: A Case Study of Qingduizi, UIA 2017 Seoul World Architects Congress, Seoul: Korea.

Li Bing, Miao Li, 2014. Origin and Evolution of Irregular Shaped Ancient Towns: A Case Study of Lijiang Ancient Town, Yunnan Province . Huazhong Architecture, 2014 (11), p. 151156.

Liu Chenglong, 2017. Research on the Form of Qingduizi Ancient Town From the Urban Typo-Morphological View. Dalian University of Technology, China.

Li Bing, Miao Li, Liu Chenglong, Li Yanqiao, 2018. From Ancient Map to Town Plan Analysis: A Morphological Analysis of Qingduizi Ancient Town from an Urban Typo-morphological Perspective. New Architecture, 2018(02), p. 128-131.

Lv Junhua etc., 2003. Modern Urban Housing in China(18402000). Beijing: Qinghua University Press.

Niu Zheng, 2019. Urban-Plan Morphological Analysis: A Case Study of Xiongyue Ancient City from the Perspective of Typological Morphology. Dalian University of Technology, China.

Shao Yong, Hu Lijun, Zhao Jie, Chen Huan, 2016. A Research on the Conservation Plan of the Human-Habitat World Heritage : Case Study of Pingyao Ancient City. Urban Planning Forum, 2016(5), p. 94-102.

Wang Guixiang etc. 2013. Cities and Architecture of Ming Dynasty. Beijing: China architecture \& building Press.

Xue Fengxuan, 2019. Chinese City and Evolution of Civilization. Beijing: Beijing United Publishing CO. Ltd. 